\title{
Proposals to increase the motorway speed limit by 10 mph
}

Any potential economic benefit is likely to be outweighed by the adverse effects on health

\author{
Jamie Lopez Bernal academic clinical fellow in public health ${ }^{1}$, Martin McKee professor of European \\ public health ${ }^{2}$
}

${ }^{1}$ London School of Hygiene and Tropical Medicine, London WC1H 9SH, UK; ${ }^{2}$ European Centre on Health of Societies in Transition, London School of Hygiene and Tropical Medicine

By 2013 the speed limit on motorways in England and Wales could increase from $70 \mathrm{mph}(113 \mathrm{kph})$ to $80 \mathrm{mph}$ if the coalition government has its way. Its stated aim is to achieve "hundreds of millions of pounds of benefits for the economy," and it dismisses concerns about health consequences, claiming that advances in car safety have resulted in deaths on British roads falling by more than $75 \%$ in the past 55 years and that almost half of all drivers break the current limit anyway. ${ }^{1}$ Are they right to dismiss these concerns so lightly?

The current $70 \mathrm{mph}$ speed limit was trialled in 1965 as a direct response to a series of fatal multiple collisions in fog. Before then speed was unrestricted outside built-up areas. By 1967 the Road Research Laboratory concluded that this restriction had led to a reduction in road fatalities, ${ }^{2}$ and Barbara Castle - then minister of transport - made it permanent. Since then the number of serious and fatal accidents has continued to fall and the United Kingdom now has one of the lowest rates of road deaths worldwide. ${ }^{34}$ Elsewhere, speed limits vary from $55 \mathrm{mph}$ on the freeways in some parts of the United States to no upper limit on large parts of the autobahns in Germany.

It is intuitive that higher speeds will result in more collisions and that collisions at such speeds are likely to result in more serious injuries and deaths, a perception supported by the evidence. Research in several countries including the UK has shown an exponential increase in the number of crashes involving injuries and deaths with higher speed. ${ }^{5-8}$ However, the health consequences extend beyond road safety. They include greater emissions and consequent air pollution, and, potentially, rising levels of obesity as a result of increased car use among those taking advantage of shorter journey times. ${ }^{9} 10$ The crucial question, however, is what happens when speed limits change. Several natural experiments in the past 20 years can provide insights. In general, where speed limits have been reduced, injuries and fatal crashes have decreased; conversely where speed limitshave been increased, the number of deaths has risen substantially. ${ }^{58}$ The example that is arguably the most comparable to the UK proposal was the increase in speed limits in many US states after 1995 when the national maximum speed limit, introduced in response to the 1974 oil crisis, was repealed-limits on interstate highways and freeways were increased, typically from $65 \mathrm{mph}$ to $70-75 \mathrm{mph}$ or from $55 \mathrm{mph}$ to $60-65 \mathrm{mph}$. This was associated with a $16.6 \%$ increase in deaths. ${ }^{11}$ However, a higher speed limit may persuade more people to use their cars rather than other forms of transport, so the increase in deaths may reflect both greater traffic volumes and increased collision risk. Of course, as the government rightly notes, many people already drive above the speed limit, but it is difficult to believe that they will resist the temptation to continue to exceed a higher limit. On this evidence, the government's dismissal of adverse health effects seems, to say the least, shaky.

Neither is it clear where it obtained evidence for the alleged economic benefits of its proposal. Heavy goods vehicles would still be limited to $60 \mathrm{mph}$, and because most work related driving in smaller vehicles takes place during the busiest periods, when roads are already overcrowded, it is difficult to see how journey times will be greatly reduced. The anticipated rise in collisions may itself slow traffic. Potential negative economic effects must also be considered, such as those set out in the government's own valuation of road accidents and casualties, ${ }^{3}$ not least of which are increased healthcare costs and depletion of labour supply from those killed and injured. Indeed, given that the incidence of road traffic injuries is highest among those of working age, these adverse economic consequences may be considerable. $^{5}$

If the government was serious about achieving economic benefits it would consider investing in alternatives with a less negative health impact, such as public transport. Examples include extending coach and bus lanes on motorways during busy periods or subsidising rail fares, rather than the planned increases in the cost of travelling on the trains that the transport secretary has described as "a rich man's toy." 12 
In the light of this evidence, it is difficult to see the proposal to raise the speed limit as anything other than a populist gimmick, albeit one that may now be less popular after the recent tragic loss of life on the M5 motorway. ${ }^{13}$ Given the clear negative public health and environmental effects, the government must show substantial countervailing economic benefits that cannot be achieved in other ways. This may be quite a challenge.

Competing interests: All authors have completed the ICMJE uniform disclosure form at www.icmje.org/coi_disclosure.pdf (available on request from the corresponding author) and declare: no support from any organisation for the submitted work; no financial relationships with any organisations that might have an interest in the submitted work in the previous three years; no other relationships or activities that could appear to have influenced the submitted work.

Provenance and peer review: Not commissioned; externally peer reviewed.

1 Department for Transport. Government proposes 80mph motorway speed limit. 2011 www.dft.gov.uk/news/press-releases/dft-press-2011100

2 Hansard. Roads (70 m.p.h. speed limit). 1967;750:821-8.
3 Department for Transport. Reported road casualties in Great Britain: annual report 2010 2011. www.dft.gov.uk/statistics/releases/road-accidents-and-safety-annual-report-2010. 4 WHO. Global status report on road safety: time for action. 2009. www.un.org/ar/roadsafety/ pdf/roadsafetyreport.pdf.

5 WHO, World Bank. World report on road traffic injury prevention. 2004. http://whqlibdoc. who.int/publications/2004/9241562609.pdf.

6 Finch D, Kompfner P, Lockwood CR, Maycock G. Speed, speed limits and accidents. Transport Research Laboratory. 1994.

7 Nilsson G. The effects of speed limits on traffic accidents in Sweden. Swedish National Road and Transport Research Institute. 1981.

8 Sliogeris J. 110 kilometre per hour speed limit: evaluation of road safety effects. VicRoads, 1992.

9 Committee on Climate Change. Meeting carbon budgets-3rd progress report to parliament. 2011. http://hmccc.s3.amazonaws.com/Progress\%202011/CCC Progress\% parliament. 2011. http://hmccc.s3.amazonaws.com/Progress $\% 20201$.

10 Woodcock J, Banister D, Edwards P, Prentice AM, Roberts I. Energy and transport. Lancet 2007;370:1078-88.

11 Farmer CM, Retting RA, Lund AK. Changes in motor vehicle occupant fatalities after repeal of the national maximum speed limit. Accid Anal Prev 1999;31:537-43.

12 Trains are a rich man's toy, says transport secretary. BBC News 2011. www.bbc.co.uk/ news/uk-politics-14904610.

13 Adetunji J. M5 crash: several dead in "worst collision in memory." Guardian 2011. www. guardian.co.uk/uk/2011/nov/05/m5-crash-feared-dead-collision? INTCMP=ILCNETTXT3487.

Cite this as: BMJ 2011:343:d7790

(c) BMJ Publishing Group Ltd 2011 